\title{
FINANCIAL PROFITABILITY AND RESOURCE PRODUCTIVITY ANALYSIS OF GARDEN PEA (PISUM SATIVUM L.) PRODUCTION IN DHANKUTA, NEPAL
}

\author{
S. Gahatraj ${ }^{1 *}$ and R. Uprety ${ }^{2}$ \\ ${ }^{1}$ Agriculture and Forestry University, Bharatpur 44200, Chitwan, Nepal \\ ${ }^{2}$ Food Security and Agribusiness Promotion Division, Ministry of Land Management, \\ Agriculture and Cooperative, Province 1, Biratnagar, Nepal
}

\begin{abstract}
Garden pea is one of the economically and nutritionally most important winter vegetable crops in Nepal. Garden pea production is an emerging farm enterprise of Nepalese farmers of Eastern hill and mountain. The study was conducted to determine profitability, to investigate whether factors of production are being used in economic way, and to find out extension strategies for increasing income of farmers in Dhankuta district of Eastern Nepal. A total of 120 garden pea producing farmers, (60 from Chhathar-Jorpati Rural Municipality and 60 from Mahalaxmi Municipality of Dhankuta), were randomly selected and interviewed using semistructured interview schedule. Descriptive statistics and Cobb-Douglas production function were used to analyze the collected data. The benefit cost ratio (3.54) indicates that the garden pea production in study site was profitable with productivity of $6.59 \mathrm{Mt} \mathrm{ha}^{-1}$ per hectare. The production function revealed that cost on seed and labor have statistically significant effect on gross returns. In contrast, the effect of cost cost on plant nutrients and pesticides were not statistically significant. The sum of regression coefficients was 1.04 which indicates that production function exhibited an increasing return to scale. Thus, extension strategies should be primarily focused on introducing high yielding varieties, use of high quality seeds, providing trainings on improved farming practices, increasing value addition practices and strengthening market infrastructures.
\end{abstract}

Keywords: Garden pea, Benefit-cost ratio, Cobb-Douglas production function, Resource productivity,

\section{INTRODUCTION}

Garden pea (Pisum sativum L.) is a most important vegetable cash crop in Eastern hill of Nepal. Fresh green seeds, tender pods, green immature peas and dry peas have

\footnotetext{
"Corresponding author: sachingtj19@gmail.com
} 
always high market demand (Poudel et al., 2017). It is an annual winter leguminous food crop having always high demand in market. In Eastern hill of Nepal, the area under cultivation, production and productivity is 1210.5 hectare, $8596.9 \mathrm{Mt}$ and 7.1 Mt respectively. Similarly in Dhankuta district, the area under cultivation, production and productivity are $320 \mathrm{ha}, 3550 \mathrm{Mt}$ and $11.1 \mathrm{Mt} \mathrm{ha}^{-1}$ (ABPSD, 2016). Area under garden pea production in Dhankuta district is the second largest in Eastern hill. Garden pea, produced in eastern hills of Nepal has high potentiality to be exported to different districts of Nepal as well as to neighboring countries, including India, Bhutan, and Bangladesh. Garden pea occupied the first position among vegetable exported to India from the Eastern region through Pashupatinagar customs, Ilam during 2010 to 2014 and third position during 2014-15 (Ojha, 2016). Moreover, garden pea has nutritional and medicinal importance. It is rich source of starch, digestible protein, fiber, vitamins, minerals (potassium, magnesium and calcium), nutraceutical compounds and natural anti-oxidants (Dahl et al., 2012). Pea seed meal is also an important protein-energy supplement in fish and animal feed ration (Gouveia and Davies, 1998). Moreover, field pea hay is possible to enhance feed value of diet, to improve milk production; especially, milk fat in buffaloes and cattle (Hayashi et al., 2007).

\section{MATERIALS AND METHODS}

\section{Study Area and Sampling Design}

The study site is located at $27^{\circ} 06^{\prime} \mathrm{N}$ latitude and $87^{\circ} 40^{\prime} \mathrm{E}$ longitude with an elevation of 2150 masl. A total of 120 garden pea producing farmers, 60 from Chhathar-Jorpati Rural Municipality and 60 from Mahalaxmi Municipality of Dhankuta district of Province 1 of Nepal were selected in simple random sampling technique.

\section{Data Collection and Analysis}

Primary data were collected through face to face interview by use of pre-tested semistructured interview schedule during May-June, 2018. Collected data were analyzed using SPSS (version 16) and MS Excel software.

\section{Cost and Return Analysis}

The total variable costs of garden pea production was calculated by covering all the variable inputs such as seed cost, organic manure cost, chemical cost, pesticide cost, and labor cost at their current market prices. All the cost were taken in Nepali Rupees (NRs.) ha ${ }^{-1}$

Total Variable Cost $=\mathrm{C}_{\text {seed }}+\mathrm{C}_{\text {organic manure }}+\mathrm{C}_{\text {fertilizer }}+\mathrm{C}_{\text {pesticide }}+\mathrm{C}_{\text {labor }}$

Where, $\mathrm{C}_{\text {seed }}=$ cost on seed $\left(\mathrm{NRs} . \mathrm{ha}^{-1}\right), \mathrm{C}_{\text {organic manure }}=$ cost on organic manures $\left(\mathrm{NRs} . \mathrm{ha}^{-1}\right), \mathrm{C}_{\text {fertilizer }}=$ cost on fertilizer $\left(\mathrm{NRs} . \mathrm{ha}^{-1}\right), \mathrm{C}_{\text {pesticide }}=$ cost on pesticides $(\mathrm{NRs}$. $\mathrm{ha}^{-1}$ ) and $\mathrm{C}_{\text {labor }}=$ cost on human labor (NRs. ha $\left.{ }^{-1}\right)$. 
Similarly, Gross return $=$ total quantitiy of garden pea produced $\times$ average price of garden pea

\section{Gross Margin Analysis}

Gross margin was calculated to have estimation of difference between the gross return and variable costs (Dhakal et al., 2015). Gross margin was calculated by using the formula given by Olukoshi et al. (2006), which is as following;

Gross Margin (NRs. ha $\left.{ }^{-1}\right)=$ Gross Returns (NRs. ha ${ }^{-1}$ ) - Total Variable Cost (NRs. $\mathrm{ha}^{-1}$ )

\section{Benefit Cost Analysis}

The economic performance of a business can be determined most efficiently by the benefit cost analysis method. It is used to compare benefit per unit of cost (Dhakal et al., 2015). Undiscounted benefit cost ratio was estimated by using formula;

$\mathrm{B} / \mathrm{C}$ Ratio $=\frac{\text { Gross return }}{\text { Total variable cost }}$

\section{Resource Productivity Analysis}

The econometric model, Cobb-Douglas Production Function, is a most commonly used technique to represent the technological relationship between amounts of all inputs and output that can be produced by those inputs i.e., input-output relationship (Balogun and Ogheneruemu, 2012). Cobb-Douglas Production Function was used to represent relationship between various inputs used and output produced. It determines the contribution of different factors on production of garden pea. CobbDouglas production function examines the resource productivity, efficiency, and return to scale (Dhakal et al., 2015). The form of Cobb-Douglas production function is following;

$\mathrm{Y}=\mathrm{aX} \mathrm{X}_{1}^{\mathrm{b} 1} \mathrm{X}_{2}^{\mathrm{b} 2} \mathrm{X}_{3}^{\mathrm{b} 3} \mathrm{X}_{4}^{\mathrm{b} 4} \mathrm{e}^{\mathrm{u}}$

Where, $Y=$ Gross return (NRs. $\mathrm{ha}^{-1}$ )

$\mathrm{X} 1=$ cost on source of seed $\left(\mathrm{NRs} . \mathrm{ha}^{-1}\right), \mathrm{X} 2=$ cost on plant nutrients $\left(\mathrm{NRs} . \mathrm{ha}^{-1}\right), \mathrm{X} 3$ $=$ cost on pesticides $\left(\mathrm{NRs} . \mathrm{ha}^{-1}\right), \mathrm{X} 4=$ cost on human labor (NRs./ha), e $=$ Base of natural logarithm, $\mathrm{u}=$ Random disturbance term, $\mathrm{a}=$ constant and b1, b2, b3, and b4 are coefficient of respective variables.

The linearised form of above Cobb-Douglas production function is expressed as following;

$\ln Y=\ln a+b_{1} \ln X_{1}+b_{2} \ln X_{2}+b_{3} \ln X_{3}+b_{4} \ln X_{4}+u$

Where, $\ln =$ Natural logarithm, and $\mathrm{u}=$ Error term 


\section{RESULTS AND DISCUSSION}

\section{Contribution of garden pea on farmers' total income}

Vegetable is a major source of income of Nepalese farmers. In study area, major cultivated vegetables were mainly temperate vegetables, which were: cabbage, cauliflower, garden pea, broad leaf mustard, raddish, capsicum, etc. (Fig. 1). From the study, it has been found that income from garden pea production contributes a major part of total income from vegetable in Dhankuta district, Nepal. Income from garden pea had second highest contribution (29\%) on total income from vegetables (Fig.1).

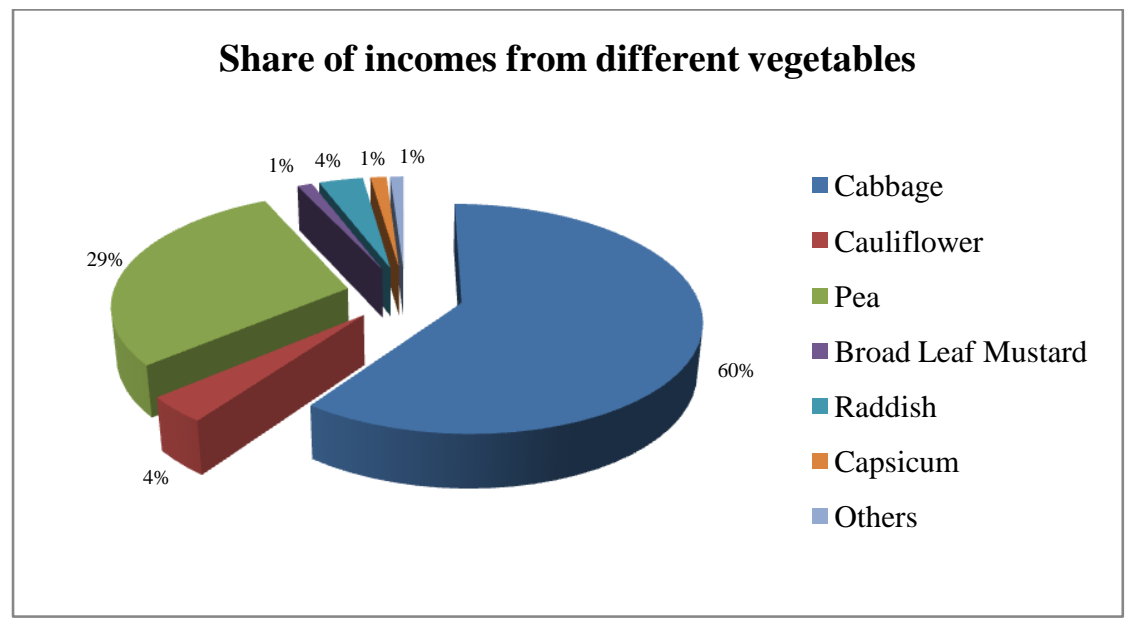

Figure 1. Share of different vegetables on farmers' total income

\section{Cost of production}

The largest proportion of the cost of garden pea production was found to be occupied by seed cost $(45.92 \%)$ followed by human labor cost $(44.41 \%)$. The estimated cost on seed cost was NRs. $24295.97 \mathrm{ha}^{-1}$ (Table 1). The cost on chemical fertilizer and pesticides (Fig. 2) were very low because garden pea being leguminous crop; nitrogen fixing crop, only source of phosphorus and potash are necessary to be supplied. The production activities that require human labor are land preparation, sowing, manure application, irrigation, harvesting and packaging. The manure cost was estimated to be NRs. $3938.47 \mathrm{ha}^{-1}$, which occupied $7.44 \%$ of total variable cost of production (Table 1). Poultry manure and farm yard manure (FYM) were major organic manure easily available and commonly used in garden pea production in study area. Application of FYM + poultry manure gives significantly higher pod yield (Gopinath and Mina, 2011). The irrigation cost was negligible because most of the farming was rainfall dependent. Weeding was not in trend for garden pea in study area. Dense foliage of garden pea is able to check weed growth up to considerable extent. 
Table 1. Total variable costs of garden pea production (NRs. ha $\left.{ }^{-1}\right)$

\begin{tabular}{ccc}
\hline Inputs & Mean & Percentage \\
\hline Seed & 24295.97 & 45.92 \\
Manure & 3938.47 & 7.44 \\
Fertilizer & 1051.34 & 1.99 \\
Pesticide & 130.36 & 0.25 \\
Labour & 23497.49 & 44.41 \\
\hline Total variable cost & 52913.63 & 100 \\
\hline
\end{tabular}

Source: Field Survey, 2018

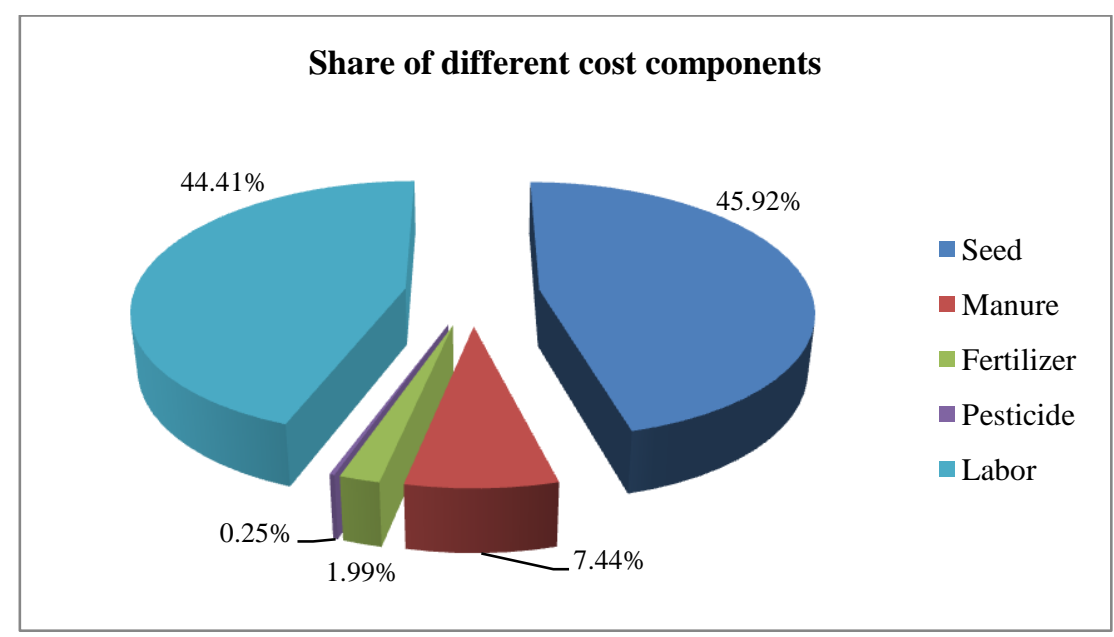

Figure 2. Share of different cost componets of garden pea production

\section{Return from garden pea production}

Farmers in the study area were producing garden pea on an average at 0.41 hectare of land. The average productivity of garden pea production was $6.59 \mathrm{Mt} \mathrm{ha}^{-1}$ at study area; however, it is lesser than average of Dhankuta district (AICC, 2017). It is because most of the farmers $(61.67 \%)$ had grown Arkel variety having production potential 5-7 $\mathrm{Mt} \mathrm{ha}^{-1}$ (AICC, 2017). The average farmgate price of garden pea was estimated to be NRs. 26.35 per kg. The total variable cost and gross return of garden pea production were estimated to be NRs. 52913.63 and NRs. 181650.78, respectively (Table 2.). Total fixed cost (TFC) used for garden pea production was mainly cost on land rent for crop duration. The overall benefit cost ratio of garden pea production considering total variable cost was estimated to be 3.54. This implies that garden pea production is a highly profitable farm enterprise for farmers in Eastern hill of Nepal. 
Verma et al. (2015) had carried out similar study, which found the benefit cost ratio of garden pea in large size farm to be 2.8, whereas lesser benefit cost ratio in smaller farms. The benefit cost ratio of garden pea at study site was found to be very high; it might be due to low costs (less than 10\% of TVC) incurred in manure, fertilizers, and pesticides (Table 1.). Garden pea is a leguminous crop; it fixes nitrogen because of which fertilizer application is reduced.

Table 2. Economic statement of garden pea production in Dhankuta, Nepal, 2018

\begin{tabular}{|c|c|}
\hline Measuring Criteria & Average value \\
\hline Area (ha) & 0.41 \\
\hline Productivity $\left(\mathrm{Mt} \mathrm{ha}^{-1}\right)$ & 6.59 \\
\hline Average Revenue (NRs. $\mathrm{Kg}^{-1}$ ) & 26.35 \\
\hline Gross Return (NRs. $\mathrm{Kg}^{-1}$ ) & 181650.78 \\
\hline Total Variable Cost (NRs. ha ${ }^{-1}$ ) & 52913.63 \\
\hline Gross Margin (NRs. ha ${ }^{-1}$ ) & 128737.15 \\
\hline Benefit Cost Ratio & 3.54 \\
\hline
\end{tabular}

Source: Field Survey, 2018

\section{Resource productivity analysis}

Out of four independent variables included in regression analysis, cost on human labor was found to be significant at $1 \%$ level and cost on seed was found to be significant at 5\% level while cost on plant nutrient and pesticide cost were found to be non-significant in garden pea production in the study area. Garden pea production is highly labor intensive constituting a major cost of cultivation (Khunt and Desai, 1996). Being highly labor-intensive crop, it is potential to provide ample employment to particularly small and marginal farmers (Singla et al., 2006). The regression coefficient of seed cost was 0.31 . This indicates that with $1 \%$ increase in seed cost, gross return would increase by $0.31 \%$. Similarly, $1 \%$ increase in human labor cost, gross return would increase by $0.72 \%$. The sum of regression coefficient of all inputs used in production turned out to be 1.044 (Table 3). It indicates the production function exhibit in increasing return to scale. The sum of regression coefficient (1.044) implies if all inputs used in production are increased by unity, the gross returns will increase by 1.044 . 
Table 3. Estimated value of coefficients and related statistics of Cobb-Douglas production function of garden pea production in Dhankuta. 2018

\begin{tabular}{lccccc}
\hline Factors & Coefficient & Standard Error & t-value & p-value \\
\hline Constant & 1.72 & 1.34 & 1.25 & 0.2 \\
Seed cost & $0.31 * *$ & 0.113 & 2.75 & 0.007 \\
Nutrient cost & 0.006 & 0.007 & 0.75 & 0.457 \\
Pesticide cost & 0.008 & 0.01 & 0.79 & 0.431 \\
Labour cost & $0.72^{* * *}$ & 0.09 & 7.95 & $<0.001$ \\
F-value & 21.15 & & & \\
R square & 0.43 & & & \\
Adjusted R square & 0.41 & & & \\
Return to scale & 1.044 & & & \\
\hline
\end{tabular}

Note: '**' indicates statistical significance at 0.01 probability level; '***' indicates statistical significance at 0.001 probability level.

Source: Field Survey, 2018

\section{CONCLUSION}

The garden pea production was found to a most important source of income of the farmers in Dhankuta district of Nepal. The benefit cost ration clearly shows that garden pea production is profitable farm enterprise for farmers. Thus, it should be promoted in Eastern hills of Nepal. For higher productivity and profitability, extension strategies and approaches should be basically focused on following: use of high quality seed, hybrid or improved variety, training to human labor regarding good agriculture and handling practices, post harvest management operations. The formulation and implementation of plans for infrastructure development for transportation and safe-keeping (collection centre, storage, cold houses etc.) were found to be indispensible. Moreover, marketing channel strengthening and farmers' easy access to right market information on time would increase profitability of this farm enterprise. That is why, strong extension strategies and approaches from government and non-government sectors are exigent.

\section{ACKNOWLEDGEMENT}

First and foremost, we are very grateful to all the respondents of study area for providing time for interview in spite of hectic farming schedule. Furthermore, we are indebted to Harsh Hang Rai, Senior Agriculture Officer of Vegetable Zone and entire Prime Minister Agriculture Modernization Project, (PM-AMP) for providing fund to conduct survey. We are equally indebted to Agriculture and Forestry University, Chitwan, Nepal for providing all platforms. 


\section{REFERENCE}

ABPSD. (2016). Statistical information on Nepalese agriculture. Government of Nepal, Ministry of Agriculture and Cooperatives, Agri-Business Promotion and Statistics Division, Singha Durbar, Kathmandu, Nepal.

AICC. (2017). Krishi Diary. Agriculture Information and Communication Centre, Department of Agricultre, Lalitpur, Nepal.

Balogun, O.L. and Ogheneruemu, O.E. (2012). Resource use efficiency and productivity of Cocoa Farmers in Idanre LGA of Ondo State, Nigeria. American Journal of Social and Management Sciences,3(2): 60-67.

Dahl, W.J., Foster, L.M. and Tyler, R.T. (2012). Review of the health benefits of peas (Pisum sativum L.). British Journal of Nutrition, 108: 3-10.

Dhakal, S.C., Regmi, P.P., Thapa, R.B., Shah, S.K. and Khatri-Chhetri, D.B. (2015). Productivity and profitability of maize-pumpkin mix cropping in Chitwan, Nepal. Journal of Maize Research and Development, 1(1): 112-122.

Gopinath, K.A. and Mina, B.L. (2011). Effect of organic manures on agronomic and economic performance of garden pea (Pisum sativum) and on soil properties. Indian Journal of Agricultural Sciences , 81(3): 236-269.

Gouveia, A. and Davies, S.J. (1998). Preliminary nutritional evaluation of pea seed meal (Pisum sativum) for juvenile European sea bass (Dicentrarchus labrax). Aquaculture, 311-320.

Hayashi, Y., Devkota, N.R. and Kumagai, H. (2007). Effects of field pea (Pisum sativum L.) hay feeding on dry matter intake and milk production of Murrah buffaloes (Bubalus bubalis) fed rice straw ad libitum. Animal Science Journal , 78: 151-158.

Khunt, K.A. and Desai, D.B. (1996). Economic feasibility and marketing of perennial vegetables in South Gujarat. Financing Agriculture , 28(1): 9-14.

Ojha, P. (2016). A study of vegetable and fruit export from Eastern region of Nepal. South Asia Watch on Trade, Economics and Environment (SAWTEE). Kathmandu: Variety Printers.

Olukosi, J.O., Isitor, S.U. and Ode, M.O. (2006). Introduction to agricultural marketing and prices: principle and application. American Journal of Agriculture and Forestry, 2(4): 199-205.

Poudel, K., Karkee, A., Shah, M.K. and Karki, S. (2017). Performance of Garden Pea Genotypes in Eastern Hills of Nepal. Journal of Nepal Agricultural Research Council , (3): 15-18.

Singla, R., Chahal, S.S. and Kataria, P. (2006). Economics of Production of Green Peas (Pisum sativum L.) in Punjab. Agricultural Economics Research Review, (19): 237250.

Verma, A., Singh I.J., Gupta, S., Singh, S.P. and Kumar, A. (2015). Study the economic analysis and benefit-cost ratio of green pea (Pisum sativum) at different level of farm size groups. Plant Archives, 15(2): 741-742. 